\title{
The law of bare life
}

\author{
Ian Ward \\ Newcastle University \\ Correspondence email: ian.ward@ncl.ac.uk
}

\begin{abstract}
2020 proved to be a remarkable year. Not the least remarkable was the realisation that, in a moment of perceived crisis, the instinctive response of the UK Government was to sweep away various so-called rights and liberties which might, in a calmer moment, have been presumed fundamental, and to rule by means of executive fiat. The purpose of this article is to interrogate both the premise and the consequence. Because, on closer inspection, there is nothing at all remarkable about how the Government reacted, for the same reason that there was little that was unprecedented about the experience of COVID-19. History is full of pandemics and epidemics, and government invariably acts in the same way. The first part of this article will revisit a particular theory of governance, again proved by history; that which brings together 'bio-politics' and the jurisprudence of the 'exception'. The second part of the article will then revisit a prescient moment in British history; another disease, another panicked government, another lockdown. In the third, we will reflect further on the experience of COVID-19 and wonder what might be surmised from our foray into the past.
\end{abstract}

Key words: Agamben; bio-politics; Schmitt; contagious diseases; COVID-19.

\section{INTRODUCTION}

\begin{abstract}
A $\mathrm{s}$ victory is proclaimed, however warily, in the 'war' against ACOVID-19, we are invited to reflect upon a very strange couple of years. ${ }^{1}$ Of course, we could decline the invitation, as Dryden famously did of the 'great plague' of 1665. Preferring in his poem Annus Mirabilis to breeze over the buboes and focus on a series of naval victories over the Dutch. As for the 'Great' Fire of London, which followed very hot on the heels, an opportunity for the king to rebuild a city of 'more precious mould'. ${ }^{2}$
\end{abstract}

1 For a commentary on the deployment of militarised rhetoric to help regulate popular fears in moments of perceived crisis, see J Bourke, Fear: A Cultural History (Virago 2005) x-xi, and also 311.

2 J Dryden, 'Annus Mirabilis' in K Walker (ed), John Dryden: A Critical Edition of the Major Works (Oxford University Press 1987) 1.1169, at 69. There is brief allusion, at l.1066, to the 'spotted deaths' which preceded the fire, a divinely ordained punishment for the sin of regicide. Nothing more. 
Samuel Johnson would later wonder at the tone, assuming that Dryden was just glad that things had not got worse. ${ }^{3}$

Less easy this time. A fascinated media, an enchanted populace, an economy laid waste, a death toll running to hundreds of thousands, and still climbing. ${ }^{4}$ People will demand answers. A judicial inquiry into the handling of the COVID-19 crisis is scheduled for summer 2022. Whilst its ambit is still to be determined, it is reasonable to suppose that it will be mostly concerned with the evidence of assorted politicians and civil servants, along with myriad modellers, virologists and National Health Service (NHS) trust executives. All to tell their particular stories and, in many cases, make their excuses. ${ }^{5}$ For which reason there will probably be a fair number of lawyers hovering in the background too.

There will be fewer historians and philosophers. Which is regrettable, because there are ways, other than the algorithmic, to model a crisis. There is human nature to be accounted, and there is the past. Both of which militate against the thought that we might be surprised by much of what has happened over the last year. If there is one thing which history tends to prove, time and again, it is the predictability of the allegedly unpredictable. ${ }^{6}$ History is littered with pandemics

3 At least not yet. By the time that Annus Mirabilis was rolling off the presses in early summer 1667, the Dutch had avenged the defeats of the previous year. Sailing up the Medway as far as Chatham, where the Royal Navy was in dock, having run out of money, and thus sailors, firing 13 warships and towing away the flagship The Royal Charles.

4 Precise numbers are difficult to discern. As to the overall economic cost, the Centre for Economics and Business Research estimated a drop in UK 'gross value added' of $£ 251$ billion for the year running from the first lockdown in March 2020. The official COVID-19 death-rate, as of May 2021, stands at 126,000. Though the figure remains highly contestable; for reasons to which we will return. No less elusive is the likely number of lives lost as a consequence of 'lockdown', which will be counted for years to come - damage to mental health, increased substanceabuse and alcoholism, cancelled elective surgery. NHS figures suggest 36,000 cancelled cancer operations alone over the 12 months from March 2020. For a sobering set of commentaries on the latter, see the special edition of the Journal of Public Health 42(4) published in December 2020, entitled 'The Collateral Damage of Covid-19'.

5 The evidence given to the Commons Science and Technology Select Committee by Prime Minister Johnson's former 'chief of staff', Dominic Cummings, on 26 May 2021, is suggestive. An opening apology followed by seven hours blaming everyone else.

6 See here, from the slightly different perspective, of anticipating financial crises, N Ferguson, The Ascent of Money: A Financial History of the World (Allen Lane 2008) 342-344. 
and epidemics, from ancient times to modern. ${ }^{7}$ In the second part of this article we will drop back a century-and-a-half to revisit one such moment; another disease, another panicked government, another overwrought lockdown.

In truth, we hardly need to go that far. In terms of debunking the myth of the unpredictable, a generation will do. COVID-19 is the third coronavirus to reach pandemic or epidemic proportions this century, to which can be added various other viral epidemics, most obviously influenza. 8 The chances of another was even gamed, to test our preparedness. Operation Cygnus, in 2016, concluded that the UK was ill-prepared to respond to a public health crisis of the kind which was, as many advised, 'inevitable'. 9 And so it proved. An early report from the National Audit Office, in May 2021, supposing that the oftenfrenetic response of Government through much of 2020 stemmed from a longer-term failure to build-in risk management 'resilience'. In the absence of which, Government was left 'firefighting' the crisis 'from day to day'. 10

With consequences that were as predictable as the virus itself. Including the de facto suspension, by executive fiat, of various civil liberties and human rights which might, in a calmer moment, have been assumed to be 'fundamental'; from the right to protest, to the right to see family, to the right to sit on a park bench with a takeaway coffee. All very strange, dystopian indeed. But, again, no surprise. It is what government always does because it is never prepared, and it always panics. And then, in the absence of any planned mitigation, resorts to measures designed to reduce public life to its barest state. For however long it takes.

$7 \quad$ See L Moote and D Moote, The Great Plague (Johns Hopkins University Press 2004) 5-10, 271-278, noting the prevalence of plagues through history. And also the tendency of each generation to assume, for reason of 'unprecedented' scale, that their plague was somehow 'greater' than any that had gone before.

8 After SARS and swine flu, in 2003 and 2009-2010 respectively.

9 Cygnus was gamed for a flu pandemic. On the inevitability of a viral pandemic in the 'near' future, see L Borysiewicz, 'Plagues and medicine' in J Heeney and S Fridemann (eds), Plagues (Cambridge University Press 2017) 85.

10 National Audit Office (NAO), 'Initial learning from the government's response to the Covid-19 pandemic', published 19 May 2021, at 32. Amongst the most significant consequences of the lack of planning, the NAO noted, were: a failure to identify those in greatest need of shielding; the consequence of mass disruption of schooling; absence of ready facilities to administer employment support; lack of mechanisms to provide emergency financial support for local authorities; the likelihood of fraud in loan administration and public procurement contracts; and tensions in the relationship between the NHS and social care services. 


\section{BIO-POLITICS AND BARE LIFE}

Before we revisit our particular history, of lockdown in Victorian England, we might contemplate some of the philosophical implications of this 'bare' life. In order to do so we will need to situate it within the broader compass of what has become known as bio-politics. After which we will turn our closer attention to the jurisprudential corollary of life lived barely.

\section{Bare life}

The idea of 'bare life' is the focus of Giorgio Agamben's Homo Sacer, posited as the alternative to what might be variously termed the 'political', or even the 'good', life. A polarity which Agamben retrieves from classical Greece, but which finds a more modern articulation in the first volume of Michel Foucault's History of Sexuality. A concern with existence as simply that. There is an immediate resonance with Hobbes's idea of 'natural man', who contracts his way into a more secure political state. We will return to Hobbes shortly. As we will Agamben. For now, though, we should take a closer look at Foucault's variant. For which reason we must also, as a necessary preliminary, contemplate his theories of disciplinary power, and the relation of knowledge and power. The aligned 'techniques', as he termed them, of modern 'governmentality'. ${ }^{11}$

Something which has, of course, a facilitative and a constitutive dimension. In the final part of the first volume of the History of Sexuality, Foucault identified the seventeenth century as the moment when politics turned its attention to 'disciplining' the 'body as a machine'. After which it evolved into a closer interest in the 'mechanics of life' and 'biological processes'. A 'series of interventions and regulatory controls: a biopolitics of the population'. 12 The purpose of which was to control not just the quality of life, but the extent and the 'utility'. ${ }^{13}$ Amongst the many things born during the 'classical period', by which Foucault means the Enlightenment, is the idea of 'public' health. ${ }^{14}$

Something else, is the prison. The subject of what is perhaps Foucault's most renowned piece of sociological history, Discipline and Punish. Looking for a definitive expression of modernity's aspiration to 'discipline' the 'body', Foucault alighted on Jeremy Bentham's

11 M Foucault, The History of Sexuality: Volume 1 (Penguin 1990) 141.

12 Ibid 139. For a comment on the significance of this moment in the evolution of Foucault's thinking and the development of 'bio-politics' as critique, see B Golder and P Fitzpatrick, Foucault's Law (Routledge 2009) 21.

13 Foucault (n 11 above) 144.

14 For the purpose, Foucault argues, of servicing emergent capitalism. See ibid 140. 
'Panopticon'. ${ }^{15}$ In its refined form a penitential model, though conceived to be of broader application across a range of public 'spaces'. Hannah Arendt famously extended the logic to the concentration camp. ${ }^{16}$ Factories too, schools and monasteries, and, of course, hospitals.

It is no coincidence that Foucault came to the Panopticon whilst searching for the origins of an institution which was designed for the express purpose of regulating 'public health'; the mental 'hospital'. In the second part of this article, we are going to focus our attention more closely on the emergence of certain public health 'techniques' in the nineteenth century; designed more closely still to 'discipline' instances of sexual 'irregularity'. For present purposes, though, we might revisit what Foucault had to say about the 'bio-politics' of plague. Because it was here that he located the immediate stimulus for the development of these associated 'public' health 'techniques'.

Along with leprosy. The critical difference being that where lepers were cast out, plague victims were locked in the 'confused space of internment'. ${ }^{17}$ Which, at once, made dealing with plague not just a medical issue, but a political and geographical one, necessitating, if it is to be effective, a common 'disciplinary' endeavour, scientific and juridical. ${ }^{18}$ As he observed in The Birth of the Clinic, a 'medicine of epidemics could exist only if partnered by a police'. ${ }^{19}$ And it had to be effective; the acid test of the 'disciplinary' state. Not just any 'public' health crisis; but the definitive crisis. Which that state, if it is to retain any credibility in terms of securing its citizenry, must be able to resolve. Whatever it takes.

There was, then, a common denominator between these different 'disciplinary' institutions. Each sought to internalise an 'other'. Whereas, in centuries past, they might be cast out, returned to their 'natural' status, literally an 'out-law', in modernity the plagueridden are now retained within the disciplinary 'gaze' of the state.

15 M Foucault, Discipline and Punish: The Birth of the Modern Prison (Penguin 1977) 195-228.

16 The definitive statement is found in H Arendt, The Origins of Totalitarianism (Harcourt Brace Jovanovich 1973) and Eichmann in Jerusalem: A Report on the Banality of Evil (Penguin 2006). A further commentary, on point, is H Arendt, 'Social science techniques and the study of concentration camps' (1950) 12(1) Jewish Social Studies 49-64. For Agamben's intimation, see G Agamben, Homo Sacer (Stanford University Press 1998) 119-120, 166-168.

17 See Foucault (n 15 above) 232-2, and also History of Madness (Routledge 2009) $5-6$.

18 Foucault (n 15 above) 172-173, 183-185. See S Elden, 'Plague, panopticon, police' (2003) 1(3) Surveillance and Society 240, 241-243; and also M Wagner, 'Defoe, Foucault and the politics of plague' (2017) 57 Studies in English Literature 501, 502-503.

19 M Foucault, The Birth of the Clinic: An Archaeology of Medical Perception (Routledge 1973) 25. 
20 Returned to the condition of 'bare life', perhaps. But not cast-out, at least not in the prosaic sense. Agamben cites the original idea of homo sacer in 'archaic' Roman law; the 'sacred man' who 'may be killed and yet not sacrificed' ${ }^{21}$ Still within the ambit, but reduced to nothing.

The facilitative and constitutive dimensions of bio-political 'technology' are, of course, mutually sustaining. It is not just the body which is 'disciplined'. So too is the 'mind'.22 The mentally ill 'cured', the criminal 're-formed'. Something which brings us to Foucault's writings on the relation of knowledge and power, and the idea of 'governmentality'.23 The ways in which government permeates the subject. 24 There is, as Foucault argued at the outset of Discipline and Punish, "no power relation without the correlative constitution of a field of knowledge, nor any knowledge that does not presuppose and constitute at the same time power relations'. 25 Modern government is not simply a set of functioning institutions. It is far subtler, a series of interlinking and constantly mutating 'networks of power'.26 Their movements oiled by discursive tensions which are themselves constantly mutating, with varying degrees of violence; the 'battle among discourses', for the privilege of telling the 'truth'.27

Plenty here for jurists to contemplate of course.28 Not least the suggestion that the 'domain of law' should be 'viewed' henceforth 'not in terms of a legitimacy to be established, but in terms of methods of subjugation that it instigates'.29 The very 'idea of justice in itself is an idea which in effect has been invented and put to work in different

20 See Foucault (n 17 above) 439-442, discussing the like treatment of the mad and the criminal.

21 Agamben (n 16 above) 8, 71-78, 104-105.

22 See Elden (n 18 above) 248-249.

23 Again introduced at the close of the first volume of Sexuality, Foucault (n 11 above) 143-144.

24 See Golder and Fitzpatrick (n 12 above) 31, suggesting that 'governmentality' can be seen as a disciplinary precursor of 'bio-politics'.

25 Foucault (n 15 above) 27.

26 See M Foucault, 'Politics and the study of discourse' in G Burchell et al (eds), The Foucault Effect: Studies in Governmentality (Harvester 1991).

27 In A Sheridan, Michel Foucault: The Will to Truth (Tavistock 1980) 134. See also A Hunt and G Whickham, Foucault and Law: Towards a Sociology of Law as Governance (Pluto 1994) 11-14.

28 Even if Foucault seemed reluctant to describe a comprehensive legal philosophy. More a case of recovering 'fragmentary reflections on law', according to Golder and Fitzpatrick (n 12 above) 2-4, and also 17. For a comment on Foucault's resistance to prescriptive theory, see $\mathrm{J}$ Miller, The Passion of Michel Foucault (HarperCollins 1993) 200-202.

29 M Foucault, 'Two lectures' in C Gordon (ed), Power/Knowledge: Selected Interviews and Other Writings 1972-1977 (Harvester 1980) 96. 
societies' as the 'instrument' of particular interests. ${ }^{30}$ To 'arrange things in such a way that, through a certain number of means, such and such ends may be achieved'. Law as a classical 'technology' of power. ${ }^{31}$ Politics in the raw.

At this point we might return to Agamben, broadly accepting Foucault's 'genealogy'. First, the confirmation of 'bio-politics' as the grounding idea, and experience, of modernity; the 'growing inclusion of man's natural life in the mechanisms and calculations of power'. 32 Second, the confirmation of the broader sweep; of the dissonance in modernity between 'bare', and what he prefers to term 'good', life. ${ }^{33}$ Here, though, Agamben stretches the thesis. So that 'bare life' is not simply reserved for the identifiable 'out-law'. But becomes definitive of politics more generally. A 'regression', as Foucault intimates, from the aspirations of Aristotelian political ethics. ${ }^{34}$ A politics that 'knows no value ... other than life' itself. ${ }^{35}$ Life lived at its barest, the ultimate Benthamite calculus, concerned not with what is 'right', still less the 'good' or the joyous. Merely with the 'health', the functionality, of the 'body'. The desire to live crushed by the 'sacredness of life', as Walter Benjamin would later put it.36 In his Rime of the Ancient Mariner, Bentham's contemporary, Samuel Taylor Coleridge, termed it 'lifein-death' and represented it in the shape of a plague-ridden 'spectrebark'. 37

Here again we are brought back to the relation of knowledge and power, the ability to 'discipline' the political mind. Each society has its own composite 'regime of truth', fashioned by its discursive 'networks', purposed to enhance compliance. ${ }^{38}$ And a corresponding, and elided, discursive regime of fear. The consequence of this is plain enough. It might be a fear of a warring neighbour, or some murderous terrorists,

30 M Foucault, 'Debate with Chomsky' in $\mathrm{P}$ Rabinow, The Foucault Reader (Pantheon 1984) 6.

31 Foucault (n 26 above) 95. See Hunt and Whickham (n 27 above) 40-42.

32 Agamben (n 16 above) 119-120, approving the sentiment of Foucault in Sexuality (n 11 above) 145.

33 Agamben (n 16 above) 7-10.

34 Foucault (n 11 above) 145

35 Agamben (n 16 above) 10.

36 Zur Kritik der Gewalt, discussed in Homo Sacer, Agamben (n 16 above) 66.

37 In S Coleridge, Complete Poetical Works (Oxford University Press 1969), lines 193, 202, at 194-5. For a discussion of Coleridge's implicit critique of Benthamism and his use of the plague metaphor in the Rime, see D Lee, 'Yellow fever and the slave trade: Coleridge's The Rime of the Ancient Mariner' 65 (1998) English Literary History 675, 686-687; and I Ward, 'A painted ship and a painted ocean: Gregson $v$ Gilbert revisited' in C Battisti and S Fiorato (eds), Law and Humanities: Cultural Perspectives (DeGruyter 2019) 243-244. 
or a nasty virus. But there will always be a fear of something, and we have to be afraid, terrified of the 'spectre'. ${ }^{39}$ Otherwise there is no need for a state, at all. As Hobbes noted. It is why individuals are prepared to covenant their natural liberties to a 'sovereign', in return for the promise of security and a set of relatively constrained 'civil liberties'.40 Which might, at any given moment, be suspended or abrogated, and which brings us to the idea of the 'state of exception'.

\section{States of exception}

Homo Sacer serves as a groundwork for an essay which Agamben published eight years later, State of Exception. 41 The title is intended to resonate with the writings of the controversial Nazi kronjurist Carl Schmitt. Schmitt first ventured a nascent theory of the 'exception' in his essay On Dictatorship in 1921. But it found fuller expression, the following year, in Political Theology. The opening line of which read 'Sovereign is he who decides on the exception.'42 Schmitt thinks of it as a stress-test. When, in a moment of 'conflict', the relative strength of a sovereign-state is discovered. It does not, therefore, describe a moment of anarchy, a return to the Hobbesian 'state of nature'. Quite the opposite. 'There is no rule that is applicable to chaos.' It is, rather, a 'rule' designed to determine the stress. Which makes it an ultimate constitutional rule; the 'moment' indeed where a constitution 'proves' itself:

The exception is that which cannot be subsumed; it defies general codification, but it simultaneously reveals a specifically juridical formal element: the decision in absolute purity. The exception appears in its absolute form when it is a question of creating a situation in which juridical rules can be valid. 43

The power to make the determinative 'decision', to reshape 'juridical regulation' in the critical moment, thus defines sovereignty in 'absolute purity'.44 An evident, and not coincidental, resonance with Foucault's idea of 'disciplinarity', and the incarceration of the 'out-laws'. Cast outside, but also kept within the 'framework of the juristic'.45

39 See Bourke (n 1 above) 1, 24.

40 Agamben (n 16 above) 104-109. For a comment on this parallel, in the closer context of Foucault's writings on plague, see Wagner (n 18 above) 511.

41 G Agamben, State of Exception (Chicago University Press 2005). Originally published in Italy in 2003.

42 C Schmitt, Political Theology (MIT Press 1985) 5.

43 Ibid 16.

44 Schmitt quotes Kierkegaard: 'The exceptional will place everything in a much clearer light than the universal itself.' See Ibid 12-14, further discussed in Agamben (n 16 above) 16.

Schmitt (n 42 above) 13. 
Agamben, interestingly, is reluctant to draw such bright lines. The 'state of exception is neither external nor internal to the juridical order'. For which reason the 'problem of defining it concerns precisely a threshold', where 'inside and outside do not exclude each other but rather blur with each other'. 46 The critical insinuation here being that the 'state of exception' cannot, contra Schmitt, be said to be securely embedded within the law. It is, in fact, a state of political 'force', the 'violence' of which is obfuscated. 47 Deliberately. Commonly by means of a sustaining, and suitably terrifying, rhetoric of 'necessity'. ${ }^{48}$ How sharply we appreciate that this 'necessity' is a matter of impression will depend on how scared we are by the projected threat to our security. By the perception of 'tumultum'; which is not just how scared we might be, but how scared government is that we are not as scared as we need to be. ${ }^{49}$ The 'battle of discourses'.

There is a temptation to assign Schmitt's thesis, in turn, to history. Consonant with a peculiarly dark moment, to find a shocking realisation in the experience of Nazism. ${ }^{50}$ A temptation both enhanced, and undercut, by his broader discussion of alternative theories of dictatorship. We noted before that Schmitt had advanced a preliminary version of his theory of the 'exception' in his earlier On Dictatorship. In which he suggested that there were two kinds of dictatorship; the 'commissarial' and the 'sovereign'. The first suspends the ordinary rule of law for the period of an identifiable crisis. The latter has a more permanent form; in effect making rule by executive 'decision' the norm. 51 As we search for resonances with the 'force' of law in 2020, the distinction necessarily intrigues.

Not least because, as Agamben argues, liberal democracies are not immune from dictatorial governance. There is, on the contrary, an 'inner solidarity between democracy and totalitarianism', which 'legitimates' necessary moments of 'violence'. 52 What we might know, more familiarly, as majoritarian tyranny. The tendency of 'democratic' politics to seek refuge, in moments of crisis, in the seeming security of 'absolute' executive governance. With the cultivated support of a

\footnotetext{
46 Agamben (n 41 above) 23.

47 Ibid 50-1, 53, 62.

48 Agamben (n 41 above) 24-26, 30.

49 Ibid 42-43.

50 For a commentary on Schmitt and Nazism, see J Bendersky, 'The expendable Kronjurist: Carl Schmitt and National Socialism 1933-36' (1979) 14 Journal of Contemporary History 309-328; and also G Schwab, 'Schmitt scholarship' (1980) 4 Canadian Journal of Political and Social Theory 149-155.

51 The distinction is discussed by Agamben in Homo Sacer (n 16 above) 38, and State of Exception (n 41 above) at 33-36. For further commentary, see G Schwab, The Challenge of the Exception (Greenwood 1979) 30-37.

Agamben (n 16 above) 10.
} 
suitably terrified populace. A thesis which Schmitt advanced in a series of essays prophesying the failure of Weimar Germany; and the ease with which liberal democracy can mutate into 'sovereign' dictatorship. Most notably, perhaps, The Crisis of Parliamentary Democracy. ${ }^{53}$ In which he argued that the Weimar 'crisis' was endemic, and could only be resolved by a fundamental rewriting of the Constitution. 54

A good point, perhaps, for us to revisit a rather different moment, and a particular text, which fascinated Schmitt.55 And fascinates Agamben. ${ }^{56}$ The publication of Thomas Hobbes's Leviathan in 1650. A specific response to the establishment of the English Republic a year earlier, inaugurated with a spectacular 'act of violence', the execution of King Charles I. And a tacit re-constitution. 57 In autumn 1650, the new Republic imposed a fresh Oath of Engagement, demanding the fidelity of all citizens, in return for which, it would re-secure their civil rights. Hobbes wrote Leviathan to give a generation of distressed propertyowning royalists the excuse they needed. Hardly the first usurpation in English history, Hobbes reminded his readers. Hardly the first reconstitution either, or the first time a new oath had been designed to supersede a former. The birth of legal positivism, delivered of a very chill pragmatism.

And suggesting another pathology. In which all states are constituted by recurring moments of violence and 'exception'. And another, more famous still, in which all citizens are hauled out of their original 'state of nature', and then contract away their liberties in return for the protection of a sovereign. Taking a longer glance back through the history of political thought, Agamben wonders, along with Foucault, if this was the moment when the philosophy of the 'good life' was

53 See C Schmitt, The Crisis of Parliamentary Democracy (MIT Press 1988) 14-17, arguing that the essence of democracy is identity rather than liberty; for which reason there is nothing incompatible between democracy and dictatorship.

54 Schmitt had in mind Article 48 of the Weimar constitution, which reserved the authority to determine a moment of 'exception' to the Reich President. A power which was immediately compromised by the need for parliamentary approval. A fatal weakness, he suggested, common to liberal democracies. Schmitt (n 42 above) 11. For further commentary on Schmitt and Article 48, see Schwab (n 51 above) 37-43.

55 Schmitt (n 42 above) 33. The idea that he might be thought the 'Hobbes of the twentieth century', as George Schwab has supposed, would accordingly have appealed. See Schwab, 'Introduction' to Political Theology (n 42 above) at xiv.

56 Agamben (n 16 above) 106-109, discussing the 'state of nature' as a 'state of exception'. A subject which Agamben has treated at greater length in a short essay on revolution entitled Stasis: Civil War as a Political Paradigm (Edinburgh University Press 2015), concluding, at 34-35, that the entire philosophy of Leviathan is that of disciplining the 'body'.

57 A formal reconstitution would only come in December 1653, with the enactment of the Protectoral Instrument of Government. 
abrogated. 58 When the 'sovereign' state took over from God's divinely ordained 'lieutenant' as the guarantor of 'bare life'. Benjamin's thesis again. And Schmitt's. We might note the specific title of Political Theology. The 'theory' of the modern state as a secular 'theology', replete with an 'omnipotent' sovereign in place of an 'omnipotent' God. ${ }^{59}$ Concerned with our well-being only insofar as it consolidates our obedience.

Something, again, for us to ponder, as we take the rather shorter glance back through the history of 2020. The threat is, of course, different. In 1650 it was fear of God which animated the 'exceptional' moment. What drove Schmitt's Germany towards Nazism was a fear of Jews.60 For us, in summer 2020, it was fear of a virus; or, more particularly, the possibility that it might overwhelm our public health services. We are about to drop back a century-and-a-half to revisit another resonant moment, another disease and another panicked government. But before we do so, we might note the presence of a familiar visitor to our history. The person who awaits us, indeed, in the first pages of State of Exception.

There is no surprise in discovering that Agamben posits the alleged terrorist as the epitomic homo sacer, counter-terrorist 'law' as a classic example of 'exceptional' law. The inmates of the concentration camp established at Guantanamo Bay in early 2002 finding themselves in the much the same position as the inmates of Auschwitz and Buchenwald. Where 'bare life reaches its maximum indeterminacy'. The familiarly 'disquieting' presence placed outside the law, and within. It is difficult to imagine a more striking example of what Agamben terms the 'empty centre' of liberal legalism, the 'space of exception', where ideas of 'right' and the rule of law have no meaning. 61

A metaphor which resonates very obviously with that deployed by Lord Steyn in his caustic denunciation of Guantanamo. A 'black hole', a place of such magnetic power that nothing can escape, and from which no one can be retrieved, an 'utterly indefensible' affront to the

58 Along with Leo Strauss too: see his The Political Philosophy of Thomas Hobbes: Its Basis and its Genesis (Chicago University Press 1963) xvi, 108, 129-130, 158-161. For Agamben's surmise (n 16 above), see 106-113.

59 Schmitt (n 42 above) 36.

60 The 'enemy', upon whom Schmitt, with a sad predictability, turned in 1935, coming out in support of the Nuremberg Laws. In his later writings, Schmitt dwelt at length on politics as the 'concrete' engagement of 'friend' and 'enemy'; again deriving inspiration from Hobbes. See C Frye, 'Carl Schmitt's concept of the political' (1966) 28 Journal of Politics 813-830; and also Schwab (n 51 above) $51-5,134-138$.

61 Agamben (n 16 above) 131, and (n 41 above) 3-4. 
collected principles of due process, human rights and the rule of law. 62 Rhetoric echoed in courtrooms on both sides of the Atlantic. Justice Stevens, for example. In the case of Boumediene $v$ Bush, confirming that the provisions of the US Constitution were precisely 'designed to survive, and remain in force in extraordinary times'. ${ }^{63}$ Lord Hoffmann in the case of the 'Belmarsh detainees', suggesting that the 'real threat to the life of the nation' was the pretence that terrorism justified the suspension of basic civil liberties and human rights. 64

In his seminal discussion of the 'rule of law', Lord Bingham likewise posited counter-terrorist 'law' as a defining example of executive overreach. The sharpest representation of the 'encroachment by the state into what had been regarded as the private domain of the citizen'.65 Reaching back into history for a couple of prescient cautions, Bingham alighted on John Selden and Thomas Jefferson. In the former case, speaking to Cicero's supposition that the priority of government must be the 'security' of its citizens. There was 'not any thing in the world more abused than this sentence'. It was Selden who drafted the Petition of Right in 1628, to counter the despotic aspiration of Charles I.66 And Jefferson who re-drafted it a century-and-a-half later, to shape a nascent American Constitution. ${ }^{67} \mathrm{He}$ 'who would put security before liberty deserves neither'. ${ }^{68}$ Thomas Jefferson was not inclined to live life barely.

\section{LIFE IN BABYLON}

Time now for our piece of historical modelling. In summer 1885, a series of articles appeared in the Pall Mall Gazette entitled The Maiden Tribute to Modern Babylon. The author was an investigative journalist named William Thomas Stead. The Maiden Tribute was about the

62 J Steyn, 'Guantanamo Bay: the legal black hole' (2004) 53 International and Comparative Law Quarterly 1-15.

63553 US 723 (2008). Quoted in T Bingham, The Rule of Law (Penguin 2010) 149.

64 A v Secretary of State for the Home Department [2004] UKHL 56, paras 36, 97, 222, 226. For commentary, see A Tomkins, 'Readings of $A v$ Secretary of State for the Home Department' (2005) Public Law 259, 263-264; and T Poole, 'Harnessing the power of the past? Lord Hoffmann and the Belmarsh Detainees Case' (2005) 32 Journal of Law and Society 534-561.

65 Bingham (n 63 above) 157.

66 Selden was one of a number tasked by the House of Commons with drawing up a petition of 'grievances'. Foremost of which was the attempt to raise 'ship money' tax by prerogative, an emergency justified by the fact that there were a lot of 'pirates' about. As was usually the case.

67 For a discussion of Jefferson's influence on the drafting of the American Constitution, see L Kaplan, 'Jefferson and the Constitution: the view from Paris 1786-89’ (1987) 11 Diplomatic History 321-335. 
'horrible realities' of child prostitution in the capital. Various accounts, including one in which Stead was able to 'purchase' a thirteen-year-old girl for just $£ 5$. A publishing sensation; ratcheted by Stead's assurance that his next scoop would be about 'Princes of the Blood'. Two days after the appearance of the first of Stead's articles, it was reported that 250,000 were gathered in Hyde Park demanding that the government do something. Josephine Butler sensed 'revolution'.69 The Home Secretary wrote to Stead begging him to stop. W H Smith, presently Secretary of State for War, pulled the Gazette from his news-stands. Too little, far too late. ${ }^{70}$

\section{Dr Acton's suspicions}

There was nothing unusual in what Stead had done. Identify a 'scare' and work it; the gist of tabloid journalism. ${ }^{71}$ And Victorian England was rarely without a workable 'scare'. Rarely without a rampant disease either; typhoid, tuberculosis, cholera, scarlet fever, whooping cough. Fortunately, it had lots of doctors and scientists. Some were brilliant. John Snow, who traced the cause of the 1854 cholera outbreak in London. William Budd who developed the theory of 'contagious' disease. Joseph Bazalgette, an engineer by training, who built the sewer network that would dramatically reduce the spread of cholera. Their brilliance has endured. That of others has not. Take, for example, William Acton. In his particular moment perhaps the most famous doctor in England, and the most dangerous. William Acton specialised in sexual diseases. ${ }^{72}$ In so doing, engaging an area of medicine which fascinated his contemporaries, and sold a lot of books.

Long books, with very long titles. Such as The Functions and Disorders of the Reproductive Organs in Childhood, Youth, Adult Age, and Advanced Life: Considered in their Physiological, Social, and Moral Relations, published in 1862. The second last word is

69 Quoted in J Walkowitz, Prostitution and Victorian Society: Women, Class, and the State (Cambridge University Press 1980) 246.

70 Doubts as to the veracity of some of Stead's accounts would only later emerge. See S Robinson, Muckraker: The Scandalous Life and Times of WT Stead (Robson 2012) chs 6 and 7.

71 See here Bourke (n 1 above) xi, and 326-230, noting the prevalence of childabuse 'scares' in modern journalism.

72 He had trained as a gynaecologist in Paris. It has been suggested that much of Acton's writing on prostitution and sexually transmitted diseases was derivative, taken from Duchatelet's De la prostitution dans la ville de Paris, published in 1836. For an overview of Acton's career, and reputation, see I Crozier, 'William Acton and the history of sexuality' (2000) 5 Journal of Victorian Culture 1-27. For a broader commentary on the coincidence of science and sexuality 'scares' in Victorian England, see E Rosenman, Unauthorized Pleasures: Accounts of Victorian Erotic Experience (Cornell University Press 2003) 28-32. 
worth noting. In the main a treatise about masturbation; Acton's more particular fascination. But not his only one. Another, first published five years earlier, was Prostitution Considered in its Moral, Social, and Sanitary Aspect, in London and Other Large Cities and Garrison Towns, with Proposals for the Control and Prevention of Attendant Evils. We might spot the same word here, the fifth. A few other words too; garrison, control and evils. We will return to these shortly. In sum, William Acton viewed prostitution as a peculiarly dangerous form of sexual 'incontinence'. A 'revolting irregularity'. ${ }^{73}$ Which needed to be regularised.

Hardly, in the moment, an unusual view. An 'erotic age of anxiety', it has been said; the anxiety being mostly discovered in the behaviour of women. ${ }^{74}$ A land of 'falling angels', it was commonly surmised. None of whom fell quite so far as the prostitute or represented quite such a threat to political, and moral, order. ${ }^{75}$ The 'darkest, the knottiest, and the saddest' of social problems, according to the social critic William Rathbone Greg. ${ }^{76}$ Writing at the close of the century, Havelock Ellis would confirm that it was a 'remarkable fact that prostitutes exhibit the physical and psychic signs associated usually with criminality in more marked degree than even criminal women'. ${ }^{7}$ Gladstone famously spent his evenings wandering the streets of London trying to retrieve 'falling' women. As did Dickens, who devoted much of his spare time to running a prostitute refuge in Shepherd's Bush. 78 Dickens assumed a less censorial perspective, even supposing that a prostitute might be reformed, by training her up in an alternative profession, and showing some kindness.

Acton was not so sure. And certainly not inclined to take any risks. Prostitution represented an existential threat to the health, physical and moral, of the nation. And its empire; something to which we will

73 W Acton, Prostitution Considered in its Moral, Social, and Sanitary Aspects (John Churchill 1870) 449. The second edition essentially expands the first, incorporating additional 'observational' material. References are to this edition, unless otherwise stated.

74 See Rosenman (n 72 above) 7.

75 See M Wiener, Reconstructing the Criminal: Culture, Law and Policy 18301914 (Cambridge University Press 1994) 16-17.

76 From his essay 'Prostitution', published in the Westminster Review in 1850. Quoted in I Ward, Sex, Crime and Literature in Victorian England (Hart 2014) 121.

77 H Ellis, The Criminal (Scribner 1890) 221. Quoted in Wiener (n 75 above) 239.

78 Urania Cottage, funded by his then friend Angela Burdett Coutts, the fabulously wealthy heir to the Coutts banking fortune. They would later fall out spectacularly, when it was discovered that Dickens had been conducting a decade-long affair with a young actress named Ellen Ternan. Coutts switched her philanthropic energies to the British Goat Society and the funding of various overseas bishoprics. 
turn shortly. 'What', the doctor wondered, 'is a prostitute?' A question to which he already knew the answer:

She is a woman who gives for money that which she ought to give only for love; who ministers to passion and lust alone, to the exclusion and extinction of all the higher qualities ... She is a woman with half a woman gone, and that half containing all that elevates her nature, leaving her a mere instrument of impurity; degraded and fallen she extracts from the sin of others the means of living, corrupt and dependent on corruption, and therefore interested directly in the increase of immorality. ${ }^{79}$

We might note this word again, albeit in the negative key; immorality. Acton did not see himself as just another scientist, or indeed just another essayist. He was a guardian of the nation's morals, a sage, of the foreboding, and indeed forbidding, kind. A curator too, it has been supposed, of the composite 'mythologies' and misogynies of Victorian England. 80 Which convinced him that the real reason why women turn to prostitution has nothing to do with sex; being rarely 'troubled with sexual feeling of any kind'. And everything to do with venality. The 'natural instinct, the sinful nature' of women, 'idleness, vanity, and love of pleasure'. 81

An insight gained from another of Dr Acton's interests, in literary criticism. Very evident in the first edition of Prostitution Considered. 82 Replete with long passages on the dangers of reading novelists who empathise with these 'instincts'. Such as Dickens, whose depiction of Nancy's death in Oliver Twist had apparently brought a young Queen Victoria to tears. Acton preferred the manlier reflections of Pope and Tennyson. Pope knew a 'harlot' when he saw one, incapable of 'one gen'rous Thought'. 83 Tennyson too:

She like a new disease, unknown to men,

Creeps, no precaution used, among the crowd,

Makes wicked lightenings of her eyes, and saps

The fealty of our friends, and stirs the pulse

With devil's leaps, and poisons half the young. ${ }^{84}$

A pointed, and prescient, metaphor.

79 Acton (n 73 above) 166.

80 M Spongberg, Feminizing Venereal Disease: The Body of the Prostitute in Nineteenth-century Medical Discourse (New York University Press 1997) 46.

81 Acton (n 73 above) 165.

82 See Walkowitz (n 69 above) 46.

83 A Pope, To a Lady, from Moral Essays. Quoted in S Claggett, 'Victorian prose and poetry: science as literature in William Acton's Prostitution' (2011) 33 Prose Studies 19, 28.

84 A Tennyson, Idylls of the King, 'Guinevere', lines 514-518, quoted in Acton (n 73 above) 166. 
Less literature in the second edition of Prostitution Considered, less need. By now Acton had seen it all himself, days spent in the company of police officers checking out brothels and chatting with 'local government medical officers'. The 'fervent imagination' replaced by 'hard memory', a 'corroborative evidence' that was overwhelming. 85 And which left the doctor with just one compelling recommendation. Eschewing the possibility that prostitution might be eradicated by persuasion, Acton advised a strategy of surveillance and regulatory intervention. ${ }^{86}$ In practical terms, targeted lockdowns, reinforced by criminal law. We might term it 'whack-a-mole'. He termed it 'recognition': 'Any scheme of legislation, having for its object the regulation of prostitution, must have as its starting point the recognition of it as a system.' 87

Not always easy, especially with prostitutes of the asymptomatic variety; 'clandestine', as Acton termed them. ${ }^{88}$ Still out, wandering the streets, when they were supposed to be inside, isolating. Which is why strategies of 'recognition' were so important; testing and tracing. To discover the most morally corrupted, the most sexually deviant and, for reasons of their dissimulation, the most dangerous and the most needing of regulation. The subject of the first volume of Foucault's History of Sexuality. The application of 'techniques' originally used in response to plague epidemics now repurposed to regulate sexuality. 89 Discursive as well as structural, for 'power's hold on sex' more generally 'is maintained through language, or rather through the act of discourse that creates, from the very fact that it is articulated, a rule of law'.90 In its 'purest form', this power finds expression in legislative interventions intended to control sexual activity. ${ }^{91}$

Which is where Acton came in. Not because he was intrinsically brilliant, or indeed the converse. But because, as a 'man of science', he lent validity to the 'official fantasy'. ${ }^{92}$ One of the emergent breed of 'doctor-judges' identified by Foucault. Working the illusion that they knew the 'truth', about sex and everything else that seemed to be going wrong. He certainly seemed to know lots about masturbating teenagers, and 'degraded' prostitutes. And numbers. Acton was also an

85 Not that overwhelming in truth. In terms of 'hard' evidence, just the testaments of a couple of police officers and some anecdotal conversation. See Acton (n 73 above) 71 .

86 See S Marcus, The Other Victorians: A Study of Sexuality and Pornography in Mid-nineteenth-century England (Transaction 2009) 3-4.

87 Acton (n 73 above) vii-iii, 99.

88 Ibid 155-160.

89 Foucault (n 11 above) 3-8, 17.

90 Ibid 83.

91 Ibid 25, 33.

92 See Marcus (n 86 above) 1-2 
early-day 'modeller'. Of the revisionist kind. Estimates for the number of prostitutes working in London, or anywhere else in England, at the time, were necessarily hazy. The Society for the Suppression of Vice suggested around 80,000 in the capital. A figure accepted by The Lancet. And by Acton. The lower limit, suggested by the Metropolitan Police, was nearer to 8,000. Which might have gained something in reassurance, but lost much in terms of titillation.

Another to prefer the upper limit was Bracebridge Hemyng. The young barrister, and later short-story writer, invited by Henry Mayhew to write an appendix on 'Prostitution' for the second edition of his London Labour and the London Poor, published in 1861. Hemyng knew how to paint a lurid picture, of East End streets teeming with child prostitutes, destined to contract a venereal disease within a 'week or two' of being pimped on the streets. ${ }^{93}$ A prologue to Stead's Tribute. As to numbers, Hemyng went for the 80,000 option. At least. It is 'not improbable that it is below the reality rather than above it'. All his readers needed to know was that the 'magnitude' was truly 'frightful'.94

Hemyng was another of the new 'judges of normality', like Acton. For reason of their self-certified expertise, invited to assume a quasi-executive role in the 'discipline' of modern government.95 Acton likened himself to the 'mysterious medicine man of yet wilder tribes', necessarily 'aloof from the life' of ordinary folk.96 And thus best positioned to discipline them. Very much like Dr Hans Reiter, editor of a collection of essays entitled State and Health, published in 1942. Another expert in sexually transmitted diseases, chief medical officer for Mecklenberg-Schwerin, who spent most of the Second World War torturing inmates at Buchenwald concentration camp. ${ }^{97}$ Reiter was quite sure that the greater responsibility of medicine was to serve the state, for the 'greater health of the people'. The epitome of the bio-politician it might be said. It is by Agamben. His workplace the 'fundamental biopolitical paradigm'.98 The place where, to borrow again from Foucault, the 'strangers' are determined, and then

93 B Hemyng, 'Prostitution in London' in H Mayhew, London Labour and the London Poor (Penguin 1985) 475.

94 Ibid 476.

95 Foucault Sexuality (n 11 above) 57, and Discipline (n 15 above) 304. For commentary here, see Hunt and Whickham (n 27 above) 11-12, 50-1.

96 Quoted in Walkowitz (n 69 above) 85.

97 Captured by the Red Army, Reiter was tried at Nuremberg, where he confessed to various 'experiments' conducted in the camp. Interned briefly, and then released, his prospective value as an expert in germ-warfare outweighed other considerations. For a series of essays on Reiter's career and his subsequent trial, see volume 32(4) of Seminars in Arthritis and Rheumatism. 
detached. ${ }^{99}$ Homo Sacer closes here, in the concentration camp, life reduced to its very 'barest'.

Hans Reiter exists at the grimmer end of his professional spectrum. A little further along than William Acton; though not, perhaps, that much further. 100 Acton, like Reiter, was a man of the moment, who seized it. Taking advantage of a present sense of crisis to promote himself, and his prejudices. Shamelessly and dangerously, with tragic consequences. ${ }^{101}$ We might conclude of doctors more generally, as Thomas Carlyle did of politicians. Some are indeed brilliant; others just seem, in the fleeting second, to be so. History writes them as charlatans. Carlyle had Disraeli in mind, the 'Hebrew conjuror'. ${ }^{102}$ It is for each generation, in whatever passes for a democracy, to make its choice. And then, when it really comes to the crunch, amidst a pandemic perhaps, hope that it has chosen someone capable, rather than a clown. Or a shameless self-promoter, or a vicious sadist. We have, though, arrived at a dark place. Time for some fresh air. A trip to the seaside perhaps.

\section{Sex and the navy}

Not that fresh in truth. Or that light. The back lanes of Portsmouth docks. A risky place to be, the chances of a mugging ever-present, the still greater chances of picking up a nasty rash. There were laws in place to deal with both risks; none of which were much use. We will leave the muggings aside, and concentrate on the rashes. Which returns us to the 'evils' of prostitution. Such as it was, the common law of 'prostitution' limited itself to the crime of importuning for purposes, which might result in a fine of up to $£ 2$. Which hardly any prostitute could pay, and hardly any magistrate bothered to enforce. A negligence that attracted increasing condemnation as a particular concern started to grow in regard to the possible consequence of all the rashes. ${ }^{103}$

Which was to threaten the very foundations of empire. Venereal disease, gonorrhoea, syphilis; everyday hazards for anyone who consorted with prostitutes, as any of Acton's devoted readers would

99 Foucault (n 17 above) 206.

100 A man whose 'slipshod' research, along with his blind prejudice and overweening self-confidence, inflicted misery on thousands of women. See Spongberg (n 80 above) 50 .

101 See Marcus (n 86 above) 2-8.

102 In his essay Shooting Niagara and After?, a bitter condemnation of the 1867 Reform Act. Quoted, and discussed, in S Heffer, Moral Desperado: A Life of Thomas Carlyle (Weidenfeld \& Nicolson 1995) 358-60.

103 Harriet Martineau, for example, ascribing the seeming rise of prostitution to the 'negligence' of the police and magistracy. In her essay 'The Contagious Diseases Act as applied to garrison towns and naval stations', quoted in Ward (n 76 above) 125. 
have known. But there was a particular 'at risk' category who needed extra protection. We might term it 'shielding'. Sailors. Of which, if it was to maintain its empire, the Royal Navy needed lots. Preferably healthy, not riddled with sexually transmitted diseases. Numbers, as ever, were hazy. But the evidence of assorted local magistrates, and harassed naval officers, was enough. ${ }^{104}$ Certainly for William Acton. Who, fortunately, had a solution:

Diseased prostitutes can no longer be permitted to infest the streets and spread contagion and death at their good pleasure. They cannot be kept off the streets except by being placed in confinement, and curing their diseases seems to be the necessary accompaniment of restraining their liberty. ${ }^{105}$

Against those who would prefer a more nuanced, even sensitive, strategy, Acton had this to say: 'A little tinkering here and there, may here and there produce some good.' It will not stop an epidemic. That will require 'regular machinery, carrying out some well-considered, universally accepted and definite scheme'. ${ }^{106}$ A lockdown. No time for dithering either, still less sympathy. Prostitution Considered closed with another literary allusion. To the labours of Hercules; 'let loose upon the filthy stalls the cleansing waters'.107 Or, more prosaically, some cleansing legislation.

Suitably alarmed, Parliament passed a first Contagious Diseases Act in 1864 . To be followed by two more, in 1866 and 1869. The provisions of the 1864 Act permitted police, in 11 naval ports, to seize suspected prostitutes, so that they might be examined for evidence of a sexually transmittable disease. And then, if need be, and it usually was, to place them in 'lock-hospitals' for up to three months. Acton suggested longer, and wider. But it was a start. In 1866 the provisions were extended to a number of northern cities, where prostitution was anyway considered thoroughly undesirable. Along with all the drinking and the partying. The temperance movement was very supportive.

As was a Parliamentary Commission, established in 1868, to consider the efficacy of the existing measures. Not everyone was sure. The Chief Medical Officer, Sir John Simon, advised against radical 'extension', not least because they did not seem to be making much difference. Not though Dr Acton, whose opinions would be quoted more extensively than any other 'expert witness' in the resulting report; and far more than that of the Chief Medical Officer. Do nothing, Acton intimated, and the consequence would be apocalyptic. Lots of vicars agreed. A

104 See Walkowitz (n 69 above) 48-49, on the largely anecdotal evidence.

105 Acton (n 73 above) 240.

106 Ibid 267.

107 The allusion being to the cleansing of the Augean stables. Acton (n 73 above) 302. 
third consolidating Act was duly passed in early 1869, widening the reach of provisions across the country to 18 'subject districts'. ${ }^{108}$ We might term it 'tier-ing'.

The 1869 Act also extended the period during which a woman discovered to be infected might be interned, to nine months, and recommended an improvement in the quality of moral and religious instruction offered in the lock-hospitals. A holistic approach which earned Greg's strident approval. Not, he confirmed, the moment to listen to cavillers moaning on about civil liberties. The 'same rule of natural law which justifies the officer in shooting a plague-stricken sufferer who breaks through a cordon sanitaire justifies him in arresting and confining a syphilitic prostitute who, if not arrested, would spread infection all around her'.109

Some did though cavil. Florence Nightingale famously. Dissenting congregations too, Methodists, Quakers and Unitarians amongst the loudest. But most vociferous were early-day women's movements. The Ladies National Association produced a series of pamphlets replete with lurid accounts of forced vaginal examinations. Testaments to 'instrumental rape'.110 Scattered insinuations too, including the idea that the greater cause of venereal disease in the Royal Navy was rampant homosexuality. And the very simple fact, already intimated by the Chief Medical Officer, that lockdown seemed to be making little difference anyway. The prostitutes still needed the money. The sailors still wanted the sex.

Acton dug in. Speaking to the Medical Officers of Health in 1869, he reiterated his belief that those women being swept off the streets 'we might almost call unsexed', very nearly un-human. The critical moment, noted by Foucault, the prelude to detachment and 'confinement'. When someone is adjudged to be a 'stranger', and reduced to the barest life. ${ }^{111}$ As to the risk that the wrong women might be somehow caught up in the net; a 'remote possibility', trumpeted up by a 'shrieking sisterhood'.112 A perception written into the second edition of Prostitution Considered which appeared the following year. The intimations of 'hard memory', all the evenings spent traipsing the streets of London with local constables, peering into the 'haunts of

108 For the extent of Acton's influence in the passage of all the Acts, the 1869 one in particular, see Walkowitz (n 69 above), suggesting, at 80, that Acton was the 'principal propagandist' for legislative intervention; and Claggett (n 83 above) 19-20.

109 Quoted in Walkowitz (n 69 above) 44-45.

110 See ibid 201-204.

111 See Foucault (n 17 above) 206.

112 Quoted in Walkowitz (n 69 above) 87. 
prostitutes' and challenging 'painted' ladies. ${ }^{113}$ Never had the stables been filthier, the need for the Contagious Diseases Acts greater. There would be no repeal, at least not for a while.

Another Commission, set up in 1871, did concede the case for ending compulsory vaginal inspections. But it would be another decade before anyone acted on it. The Acts would be eventually suspended in 1883. And then repealed, three years later. Attention had anyway drifted.114 Courtesy of William Thomas Stead. The disease had not vanished, of course. Nor the prostitutes. But the empire was still intact, even if its sailors were not always. And Parliament had reconciled itself to what had been apparent to many for a long time. Speaking in Parliament, during the debates which led to the establishment of the 1871 Commission, the radical MP Jacob Bright had presented some alternative medical opinion. Most notably that of the InspectorGeneral of Army Hospitals, Frederic Skey. The 'public mind is alarmed, it has been coloured too highly'. William Acton, Bright concluded, was 'probably the most illogical man who ever put pen to paper'. ${ }^{115}$

Three years later came another report, entitled An Exposure of the False Statistics of the Contagious Diseases Act, written by an association of reformatory and refuge managers. It supposed that the 'regulationists' had systematically doctored the figures; pretending that the lockdown was doing far more good than was really the case. ${ }^{116}$ Lies, damned lies, and statistics. A quote commonly associated with Mark Twain, who attributed it, in turn, to Disraeli.117 The provenance might be uncertain, but the prescience is not. ${ }^{118}$

\section{CONCLUSION: HISTORY REPEATING}

'Those who cannot remember the past are condemned to repeat it.'119 So, famously, said the philosopher, George Santayana. The moral might seem simple enough; that history is a resource which can prevent us from making the same mistakes. Except that, as Santayana intimated,

113 Acton (n 73 above) 22-26.

114 We might though note a further consequence of the repeal. Its success emboldened the National Association to enjoin a wider campaign, to end a still longer 'state of exception', that which denied women the vote. See Walkowitz (n 69 above) 1-6, and also 254-255, suggesting that the repeal campaign energised a 'revolt of the women' against 'state intervention'.

115 HL Deb 20 July 1870, cols 574-587.

116 See Walkowitz (n 69 above) 111.

117 M Twain, Autobiography (California University Press 2010) 1.228.

118 Hardly the first time, during a public health crisis, that figures might have been over, or indeed under, inflated. Published mortality bills during the 'great' plague of 1665 were almost certainly so. See here Moote and Moote (n 7 above) 81, 121.

119 G Santayana, The Life of Reason: Reason in Common Sense (Scribner 1905) 284. 
what history really reveals is our propensity to keep repeating them. So what might we recollect from our brief journey back into the 'bare life' of mid-Victorian England?

We have already premised a couple of conclusions. First, be wary of those who would claim that a particular, and current, crisis is unprecedented. The fact-situation might be different, and the crisis genuine. But it is unlikely to be unprecedented. And the more urgently we are told that something is, and thus warrants the most dramatic of regulatory interventions, the more sceptical we should be. The more ready to interrogate what Agamben terms the 'empty centre' of the narrative. ${ }^{120}$ Where, under the guise of the 'exceptional' moment, we will find, invariably, the 'force of law'. And hear, just as invariably, the rhetoric of 'violence', all the statistics, the blood-curdling imagery. The 'imaginary landscape' of 'fear'. ${ }^{121}$ A related observation, vivid in our brief history of the contagious diseases scare, is to know your sage. The ghost of William Acton stalks every ministerial briefing.

Our second ready conclusion is a variant. Plagues are predictable, and so is the way that government will respond. This is not the place to debate the 'legality' of COVID-law. ${ }^{122}$ It is, rather, to recognise the underlying pathology. Government in 2020 reacted in precisely the same way as government reacted in 1864. And, for that matter, during the 'great' plague which Dryden dodged.123 It deployed a narrative of unprecedented crisis, declared a 'state of exception', and issued a series of executive orders, authorised, however vaguely, by statute, for the purpose of locking people down, or up. The fact that these powers were, on rare occasion, nodded through a cowed Parliament should not fool us. For the duration of the pandemic, as Lord Sumption has recently argued, the UK Government assumed 'coercive powers over its citizens on a scale never previously attempted', and did so, not only with a 'cavalier disregard' for the rule of law, but with 'minimal parliamentary involvement'. ${ }^{124}$

Sumption has been a consistent critic of 'COVID-law' and policy. A 'monument of collective hysteria and government folly'. ${ }^{125}$ Further evidence that government, when placed under pressure, instinctively presumes to rule in disregard of the law. Reducing the UK, for much of 2020, to little more than a 'police state'; where elderly dog-walkers

120 Agamben (n 41 above) 86-88.

121 Foucault (n 17 above) 361.

122 For an interesting, if early, overview, see K Ewing, 'Covid-19: government by Decree' (2020) 31 Kings Law Journal 1-24. For a more recent one, see J Sumption, Law in a Time of Crisis (Profile 2021) 220-225.

123 Moote and Moote (n 7 above) 53-55, 116-117.

124 Sumption (n 122 above) 225, 228.

125 Ibid 218. 
can be berated for having strayed too far from home; where sitting on a park-bench nibbling a hob-nob can result in a fixed-penalty fine; where young women holding a vigil for a murder victim can be violently dispersed by police 'snatch-squads' ${ }^{126}$ Hardly a testament to the health of the nation.

The conclusion is stark and unarguable. When COVID-19 arrived in the UK in spring 2020, Government responded by assuming the powers of a commissarial dictatorship. Whether or not the existential threat to the security of the nation was such as to legitimate the effective suspension of the 'rule of law' is a different question. Another for coming historians to ponder. But the bar, we might think, should be set high. Higher perhaps that the figure of 0.2 ; the percentage of the population in the UK whose deaths might be attributable, in part at least, to COVID-19.127 The question of proportion; with which

126 For Sumption's commentary on life in a 'police state', see ibid 228-230. The elderly dog-walkers were discovered in the Peaks, miles from anyone, thanks to a police drone, and then 'shamed' on various media by the local, evidently bored, constabulary. Reports of careless bench-sitters are legion. The vigil in question was held in memory of Sarah Everard, at Clapham Common in March 2021. Shocking images of burly male police officers piling into slightly built young women, quietly stood, were beamed around the world within hours. Rather obviously resonant of similar images of police officers beating-up suffragettes a century ago. History will likely judge the events at Clapham Common similarly. There were so many more examples of variously idiotic and disturbing COVIDpolicing in the moment, but a special mention, perhaps, for the West Mercia Police, who felt obliged, in the midst of a very bleak mid-winter, to remind any prospective snow-ballers that their intended activity was not amongst those which fell under the hazy rubric of 'reasonable exercise'.

127 Taken as a raw percentage of the population. The sustainability of this figure is bound to remain a matter of contention for some time yet. Not least because we do not, and probably never will, know how many of those whose death certificates recorded a positive COVID-19 test actually died as a consequence of contracting the virus. The excess mortality rate, the most reliable statistic, suggests an overall increase, across the calendar year 2020, of around $7 \%$; a rate that steadily reduced to $1 \%$ in the autumn, before rising again towards the end of the year. The consequential supposition, that a significant proportion of COVID 'deaths' were in fact attributable to mortality 'displacement', is argued in C Heneghan et al, 'Interpreting excess mortality in England: week ending 9 October 2020' (Centre for Evidence Based Medicine, 23 October 2020). And also J Aburto et al, 'Estimating the burden of the Covid-19 pandemic on mortality, life expectancy and lifespan inequality in England and Wales: a population-level analysis' (2021) 75(8) Journal of Epidemiology and Community Health, suggesting that a more credible figure for deaths caused as a direct consequence of contracting the virus during 2020 is closer to 63,000, which, if true, lowers the present bar further; from 0.2 to $0.1 \%$ of the population. On the difficulty of estimating COVID-19 related deaths, other than using 'excess mortality' figures, see $\mathrm{T}$ Beaney et al, 'Excess mortality: the gold standard on measuring the impact of COVID-19 worldwide?' (2020) 113 Journal of the Royal Society of Medicine 329-334. 
Foucault closed his History of Madness. How, in an age of pretended reason, could 'so slim an eventuality come to hold such a power of revelatory dread'? 128

And the question which Agamben has asked, repeatedly, in a series of provocative reflections on the particular experience of COVID-19. Suggestive certainly; the summer of 2020 as a moment of 'exception', during which the imperatives of 'bio-politics' swept away the pretences of liberal democracy. Schmitt's dark prophesy, of 'scientific thinking repressing the essentially juristic-ethical'. ${ }^{129}$ In a first sense, simply abrogated. The familiar 'tendency', in a crisis, to 'use the state of exception as a normal paradigm of government'.130 And in a second, overwhelmed. The irresistible 'force' of the 'great fear'. The 'situations of collective panic for which the epidemic provides once again the ideal pretext'. A paradigmatic 'object of anxiety'. ${ }^{131}$ Not merely fear in the raw, but mutating cultures of shame and 'esteem' too; face-masks, vaccine 'passports', clapping for carers. ${ }^{132}$ But rooted in fear, always. The reason why Parliament passed a series of Contagious Diseases Acts in the 1860s. And the reason why it has approved successive Coronavirus Acts in 2020. The 'force of law' cracking the veneer of legality.

Facilitated, of course, by our subscription to a particular philosophy of life which is 'bare'. Where all that matters is survival, at whatever cost. In a later 'clarification', Agamben wrote:

The first thing the wave of panic that's paralyzed the country has clearly shown is that our society no longer believes in anything but naked life. It is evident that Italians are prepared to sacrifice practically everything - normal living conditions, social relations, work, even friendships and religious or political beliefs - to avoid the danger of falling ill. The naked life and the fear of losing it, is not something that brings men and women together, but something that blinds and separates them ... And what is a society with no other value than survival? ${ }^{133}$

128 Foucault (n 17 above) 543.

129 Schmitt (n 42 above) 48.

130 G Agamben, 'The invention of an epidemic' (2020) published in (Quodlibet, 26 February 2020). Translated in 'Coronavirus and philosophers' (2020) in European Journal of Psychoanalysis.

131 M Peters and T Besley, 'Education, philosophy and viral politics' in M Peters and T Besley (eds), Pandemic Education and Viral Politics (Routledge 2020) 5.

132 In 1665 it was wearing toad-amulets, available at all reputable alchemists. In the 1870s it was the possession of 'certificates of health' stamped by a local magistrate. Prostitutes in possession of such certificates commonly charged extra and styled themselves 'Queen's women'. Something else that is predictable about a public health crisis is the emergence of new market-opportunities.

133 G Agamben, 'Clarifications' (2020) in 'Coronavirus and philosophers' (n 130 above). 
As we begin to reflect on the experience of COVID-19, the instinctive reaction will be to blame someone; careless Chinese scientists, panicked government ministers, media fear-mongers, algorithm-obsessives. The likely cast for the coming judicial inquiry; in spirit, if not always in person. But there is a darker intimation in Agamben's 'clarification', which widens the net of complicity. To us.

First, because we refuse to accept the reality that life, lived at liberty, is full of 'uncontrollable risk'.134 Second, because we are so 'sorely', and so easily, scared.135 Third, because we are so eager to believe that the risk, and the fear, might be exorcised; in days past by a man of the cloth, these days by a member of the Scientific Advisory Group for Emergencies. ${ }^{136}$ But it will never be so, for the reason that Franklin Roosevelt famously articulated. We cleave to fear, not just as a psychological, but as an emotional and cultural experience. There is 'nothing so much to be feared as fear itself'.137 The 'war' against the virus, like the 'war against terrorism', or the war against syphilitic prostitutes, is simply the latest externalisation of an inner struggle which is definitive of the human condition. As Agamben puts it, 'The enemy isn't somewhere outside, its inside us.'138

Unsurprisingly, Agamben's critique has attracted plenty of attention, mostly hostile. Too 'far-fetched'. Too heartless. The complaint of a 'selfish' libertarian. ${ }^{139}$ Liberal democracy has its place. But it must, when a crisis looms, step aside; for the greater interest. An argument which depends, of course, on accepting that liberal democracy is not, itself, the greater interest. Something to think about. As Lord Sumption again observes: 'So remarkable a departure from our liberal traditions surely calls for some consideration of its legal and constitutional basis.' 140 It says something that such a view might be

134 As Ulrich Beck termed it in his Risk Society: Towards a New Modernity (Sage 1992). Precisely the same conclusion ventured, in the closer COVID-context, by Lord Sumption (n 122 above) 233. We live in an 'age obsessed with escaping from risk'.

135 Bourke (n 1 above) 24, 56.

136 Ibid 369 , commenting on the role which science has played in spinning the illusion that we can live without risk.

137 Ibid 184, 368-372.

138 Agamben (n 133 above).

139 See, for example, Sergio Benvenuto, concluding that 'lockdown' measures represent the 'lesser' of 'evils', in 'Welcome to seclusion' (Antinomie, 5 March 2020), translated in 'Coronavirus and philosophers' (n 130 above). For more balanced commentaries, see M Peters, 'Philosophy and pandemic in the postdigital era: Foucault, Agamben, Zizek' in Peters and Besley (n 131 above) 72-77; and also G Delanty, 'Six political philosophies in search of a virus: critical perspectives on the coronavirus pandemic' (LSE 'Europe in Question' Discussion Paper 156/2020) 6-8.

140 Sumption (n 122 above) 218-219. 
considered somehow aberrant. Then again, as history time and again confirms, fear depresses thought. It is, as Agamben acknowledges, a 'bad counsellor'. Much the same was supposed in the wake of ' $9 / 11$ '. That to think about the causes of terrorism was to somehow sustain it; when precisely the converse is true. ${ }^{141}$

There may, or may not, be a rationale for 'COVID-law'. But there is no rationale for doing as Dryden might have us do. For this, put simply, is 'how freedom dies'. ${ }^{142}$ Of course, to think against the grain requires courage. And, commonly, the assistance of time. The colder light of day, in which historians tend to write their histories. We can only surmise what they will say of the 'great plague' of 2020, or the 'great scare' as it may well, in time, be renamed. A 'hard case' undoubtedly, which tested a lot of things to their limit; health services, government, us. They may be kind; though probably not. In the meantime, we can suppose a couple more prospective conclusions. They will surely notice just how easily we were terrorised into embracing a 'state of exception'. And how readily we accepted a philosophy of life that was so 'bare'. Whether they will be much surprised is a different matter.

141 See here T Honderich, After the Terror (Edinburgh University Press 2002) 1011, 59-61; and M Ignatieff, Lesser Evil: Political Ethics in an Age of Terror (Edinburgh University Press 2005) 167-168.

142 Sumption (n 122 above) 231. 